\title{
SCIENCE AND TECHNOLOGY FOR SOCIETY TOWARDS GARBAGE FARMERS IN RT09 AND RT010 / RW03 KAMPUNG BALAKANG KAMAL KALIDERES WEST JAKARTA
}

\author{
Putri Suryandari $^{1 *}$, Anggraeni Dyah ${ }^{1}$, Sri Kurniasih ${ }^{1}$ \\ ${ }^{1}$ Departement of Architecture, Faculty of Engineering Teknik, Budi Luhur University \\ *putri.suryandari@budiluhur.ac.id
}

\begin{abstract}
RW03 Kampung Belakang, Kamal Village is a RW that BPS (Bureau of Statistics) in 2016 is declared a slum area of DKI Jakarta. While Rt 09 and Rt 10 is RT which became the focus of slums in RW03. People here work as farm laborers, laundry workers and slipper factory workers in freelance.Lack of public awareness at RT.009 and RT.010 / RW.03 Kamal Village, Kalideres Subdistrict West Jakarta to live in clean and healthy environment becomes the main problem of the community. Waste contained in vacant land, drainage and roadside due to unavailability of public and private waste disposal facilities. Often leads to flooding and the incidence of unpleasant odors. Rubbish is actually a potential partner of Community. To raise the potential of garbage in Kampung Belakang, RT.009 and RT.010 / RW.03 Kamal Village, Kalideres Sub-district, West Jakarta, become a source of income and livelihood of the people there. So do change the mindset and the way people view the waste. Environmentally friendly education and waste are urgently needed.The output are 1. Recycling Clinic, 2. Fertilizer Formation and 3. Formation of Garbage Bank, through the method of handling education of handicrafts from plastic waste, making fertilizer and storing garbage in Garbage Bank. The accompaniment is carried out together with the NGOs Nyiur Budi Luhur and the Kamal Community Self-Reliance Society.Counseling activities involving volunteers from the community are appropriate, as volunteers are also part of the community. Finally, Kampung Petani Sampah in RW03 was successfully inaugurated by Kali Deres Sub-district, as well as holding a community recycling bazaar.
\end{abstract}

Keywords: Assistance, Fertilizer House, Garbage Bank, Recycling Clinic, Waste Farmer Village, Waste Recycling

\section{INTRODUCTION}

The existence of slums in big cities is one of the problems of local governments that still cannot be resolved completely until now. In Jakarta, there are still 264 RW slums, consisting of 8 RWs "slum heavy", 23 RW "slum medium", 89 RW "slum light", 144 RW "very light slums. Those who live in slum areas find it difficult to improve their quality of life except, waiting for government assistance. Every year, the DKI Jakarta provincial government has made efforts to improve the slums. DKI Government has declared that in 2019 there will be no more slums in DKI Jakarta.

RW03 in Kampung Belakang, kelurahan Kamal is a RW which by BPS (Central Bureau of Statistics) in 2016 was declared a heavy slum area of DKI Jakarta. While the Rt 09 and Rt 10 are the Rt that became the focus of the slums in RW03.

Based on our survey, a portrait of Kamal's environmental conditions is as follows: The community does not have a fixed income, the main profession is garbage scavengers, agricultural laborers and slipper factory workers.

\section{Problem}

The people's behavior towards garbage at this time is, throw it away empty land, or burn it. The drive to slums due to lifestyle that is less clean than the elements of garbage disposal, is very dominant and this is shown by the many people who litter. The river and drainage ditch were filled with garbage scattered and seemed to have accumulated long ago.

So the problem is: 
1. How to change people's mindset in order to dispose of the right garbage?

2. How to invite the community to form a Waste Recycling Clinic, a Fertilizer House and a Waste Bank?

\section{Extensive Target}

To raise the potential for waste in Kampung Belakang, RT.009 and RT.010 / RW.03, Kamal Village, Kalideres Sub-District, West Jakarta, is a source of income and livelihoods for the residents there, so there is a need for a change in mindset and the way people view waste. Education is needed on the importance of being friendly with the environment and garbage. The output target to be achieved in this mentoring program is "changing the slum without evicting" by improving itself to a clean and healthy environment for the people of RT.009 and RT.010.

The results that will be generated include:

a. Education Recycling Clinic

b. Educational Formation of Fertilizer Houses

c. Educational Establishment of a Waste Bank

\section{Methods of Activity}

a. Time and Place of Service

Community service implementation takes place at RPTRA RW03, House of the RT head and Resident's house.

The activity is carried out from March 2017 to August 2017, which is 6 months.

Mentoring is done every month in the RW 03 area.

The assistance schedule was adjusted to the capacity of the RT head and PKK RT head to gather PKK mothers.

The most effective time is 11.00 to 15.00

b. Empowerment methods and design

The plan of activities in problem solving partners is the Tri-Daya concept, among others

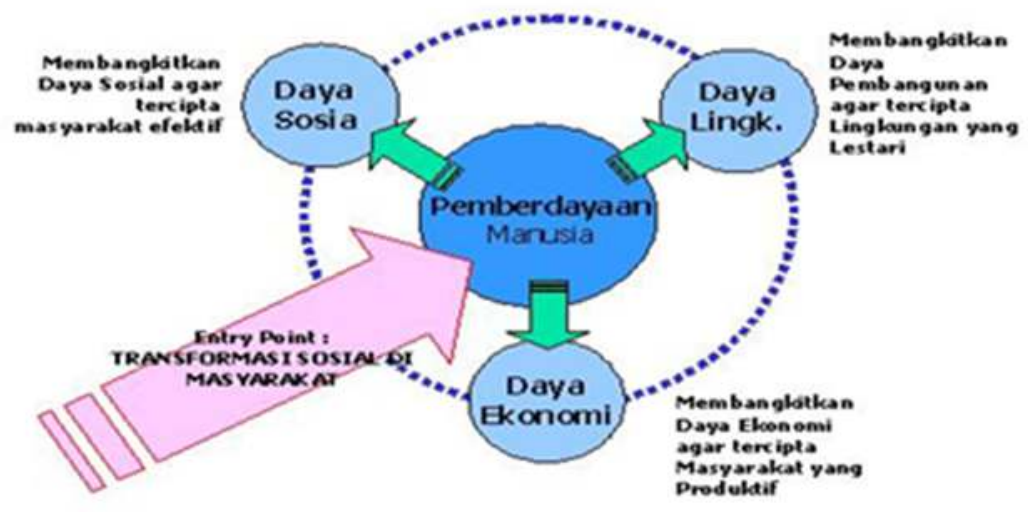

Figure 1. Tridaya Concept

1. Social Power

Invite the community to the educational process through the following approach:

a. Coordination with community leaders (RT / RW)

b. Coordination with KSM (self-help groups)

c. Activity socialization to all citizens

d. Educational processing of organic and non-organic waste 

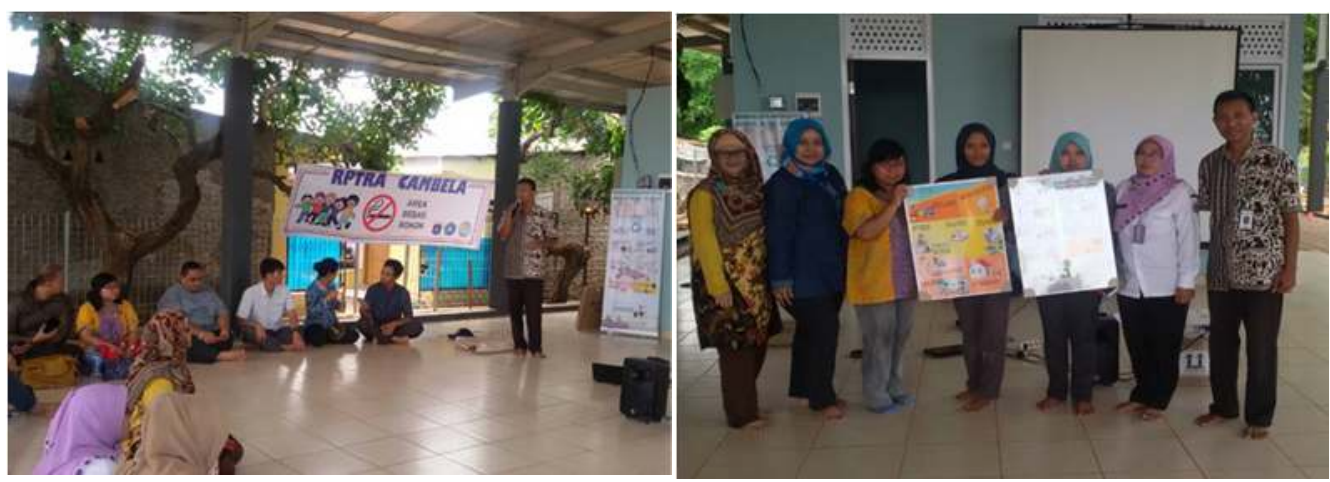

Figure 2. Activity socialization to all citizens

2. Environmental Power

Raising the potential of the environment, especially waste by:

a. look for the potential of leaf waste that can be made into craft products

b. collecting household plastic waste scattered on the streets

3. Economic Power

Make an inventory of available resources to drive the community's economic sector,

a. Data collection on trash recycling enthusiasts: organic and non-organic

b. collect garbage collectors and household waste collectors

c. Establishment of a repeat clinic for the production and sale of waste farmers' handicrafts

4. Partner Participation

During the implementation of activities, Partners participate in the implementation of the program, from the beginning to the end.

a. In the early stages of program implementation licensing, partners participate in:

- Provide information about the problems faced by partners.

- Give permission to the Budi Luhur University Architecture Study Program to conduct field studies in the partner area.

- Sign the licensing of the IbM program to the Waste Farmers Village.

b. At the implementation stage of the IbM program application to the Waste Farmers Village, partners participate in:

- Provide consumption when learning about a healthy environment, training to learn to recycle organic waste and non-organic waste, as well as training to do business from the results of recycling organic waste and non-organic waste.

- Provide a place for recycling clinics.

- Provide work equipment to create a nameplate.

c. At the final stage, report the results of program implementation to partners.

- Give permission to Budi Luhur University Architecture Study Program to monitor the sustainability of program implementation.

\section{RESULT AND DISCUSSION}

\section{Activity Outcomes Socialization}

In order to follow up the program work plan in terms of the realization of changes in attitudes and behavior of the community in treating waste. We invited the community volunteer team, namely the Community Self-Reliance Agency (BKM) Kamal and the Community Self-Help Group (KSM) Nyiur Petani sampah, as the spearhead of the approach to the community.

KSM Nyiur is a direct assistance of Budi Luhur University, its main task is as a vanguard in mobilizing the community in empowerment activities.After KSM and BKM approached the community, the community service team could more easily provide training and mentoring materials. 

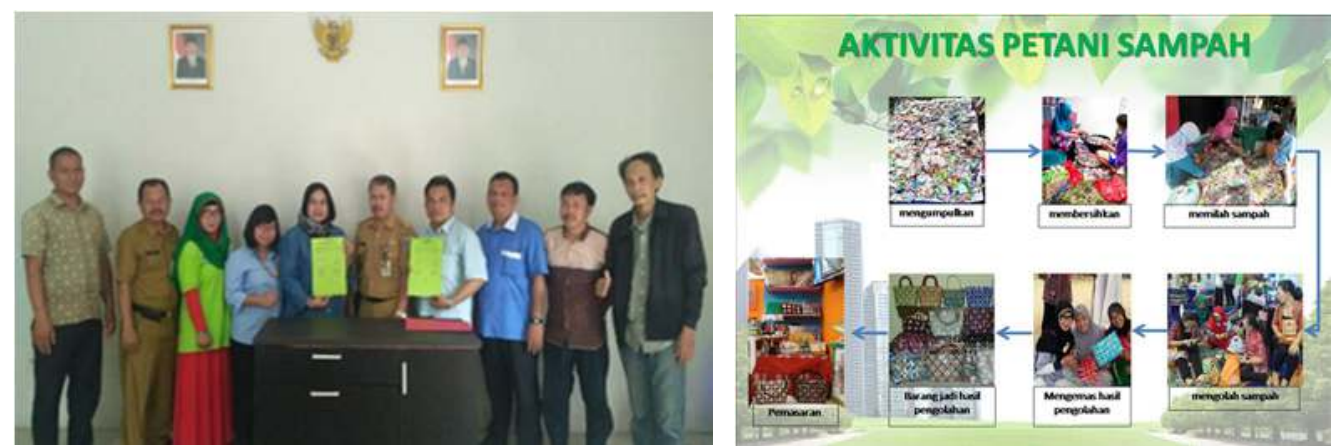

Figure 3. Recycling Education and Assistance

Mentoring activities carried out by this community service team are carried out every month, for 8 months.

1. Activity I socialization at RPTRA RW03

Attended by Chairperson RW03, Chairperson RT09, Chair RT010, Secretary of Lurah and residents RW03.This dissemination activity provides information about the program of Waste Farmers Village in RW03.Residents are directed to form management groups, namely the management of the Recycling Clinic, the Fertilizer House and the Waste Bank.The flow of waste farmer activities, among others, is like the following chart:

\section{Recycling Education and Assistance}

Here residents will be trained to become waste farmers in the recycling clinic. The method used is to use the Training of Trainner Method (TOT), which is a lecture method and then immediately practice activities.

Mentoring activities are carried out jointly with the Kamal Community Self-Reliance Agency and the Community Self-help Group for Waste Farmers.

\section{Education of Happa / Leaf waste}

Residents are educated to shed the leaves of green into transatine leaves,

After the green leaves disappear and turn into transparent leaves, the leaves are processed into handicrafts.
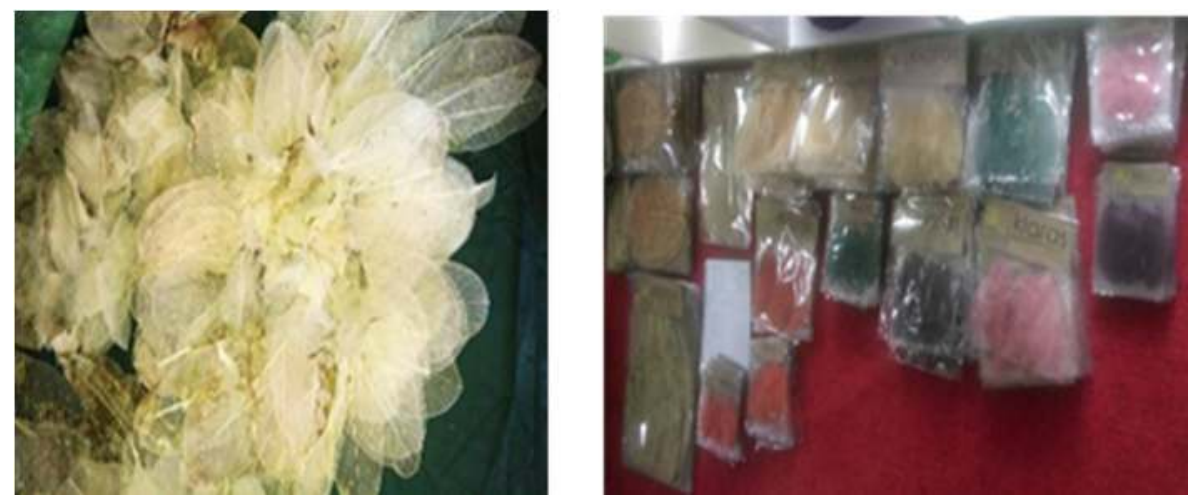

Figure 4. Education of Happa Product

2. Household plastic waste education.

Providing training in processing non-organic waste into goods that can be reused. Recycling of nonorganic waste can be used by the community itself or can be sold to the public.Residents were invited 
to collect plastic coffee waste from their homes, then were taught to wash clean garbage, dry it, and then fold it. (Figure 3.8). After the residents are good at folding, they are directed to make unique and selling designs. The handicrafts are then sweetened especially on the ropes and zippers.
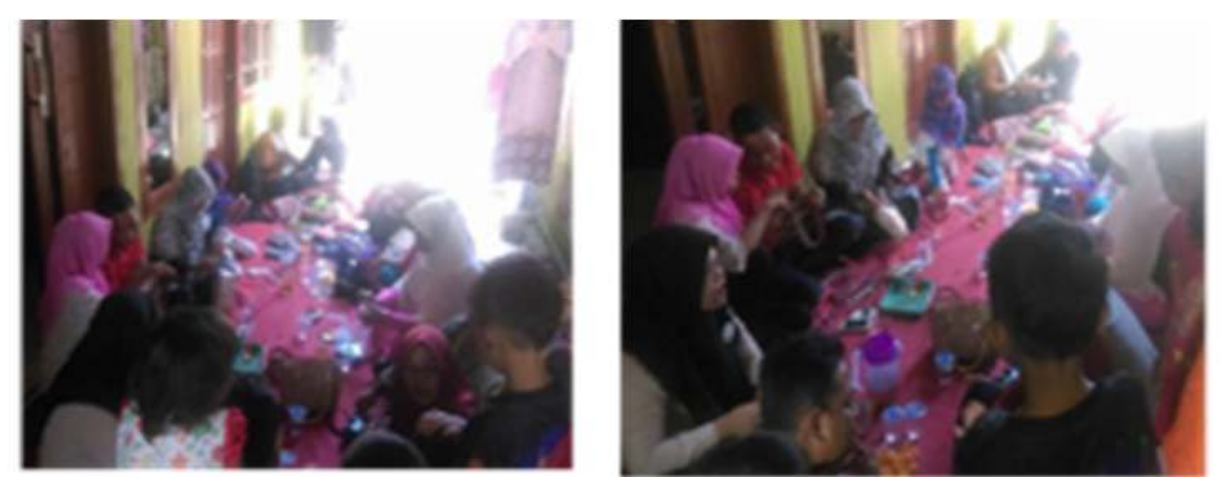

Figure 5. Household Plastic wasate Education

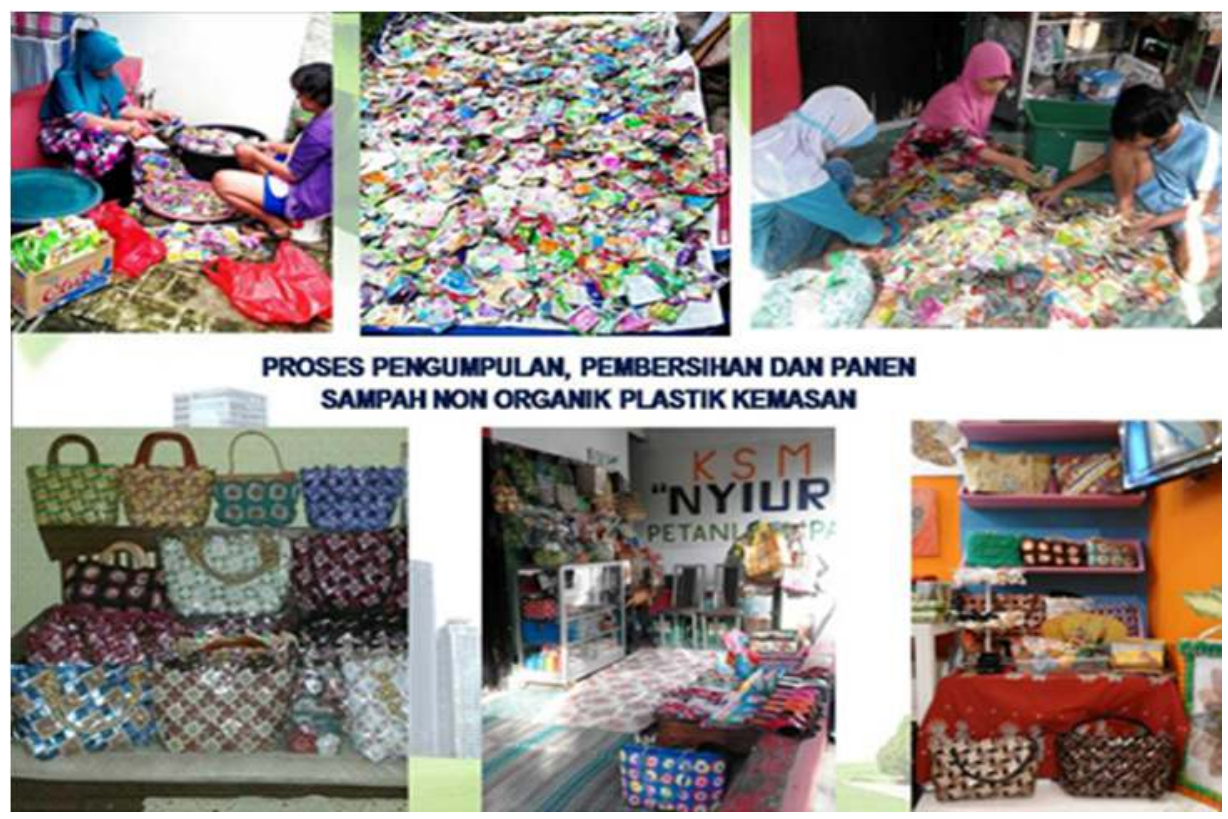

Figure 6. Recycling Product Handicraft

Mentoring activities Recycling of organic and non-organic waste is carried out within 3 months. Residents are accompanied by partners from KSM NYiur Farmers waste. The mentoring process is very good and gets enthusiasm from the community. So that for 3 months assistance has been able to produce products that have a sale value. 

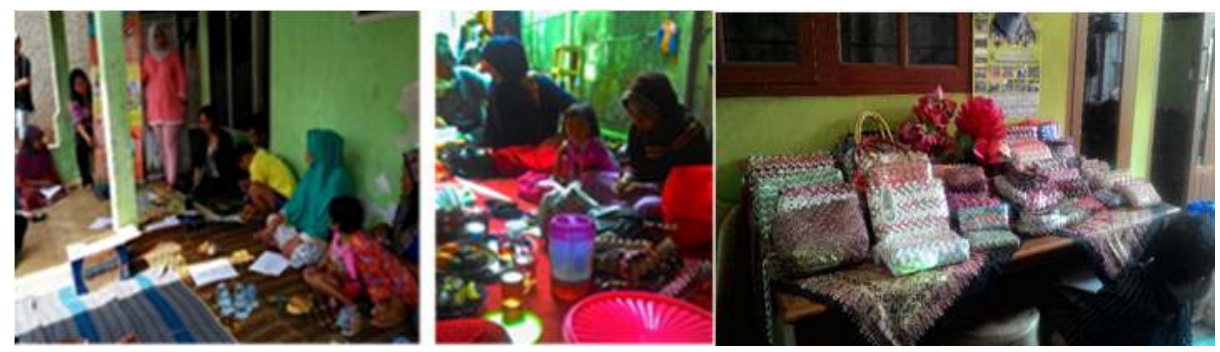

Figure 7. Education and Product Recycling

At the 4th month meeting, the Head of RW, Chairperson of RT and BKM Kamal, gathered to see the results of the community's activities in making recycled products. Officials felt the need to support activities to become more serious. So we decided to formalize the group to become the RW03 Residents Recycling Clinic.

\section{Inauguration of the Recycling Clinic}

The mechanism for the implementation of this activity was, first the management and residents of Kamal gathered at the RW. 03 Secretariat to carry out the inauguration of the Recycling Clinic. The speech was given by the chairman of LKM / BKM Kamal, Chairperson of RW.03, Kasi Kalideres SubDistrict Facilities and Infrastructure, Korkot Region 1 Kotaku DKI Jakarta, Chairperson of KSM Nyiur Universitias Budi Luhur, as well as deputy chairman of the IbM Team from the Budi Luhur University Architecture Study Program.

Speeches from community leaders are very positive and hope that this recycling clinic can be done by PKK mothers throughout the Kamal region. The Chairman of BKM Kamal will create a marketing system for mothers in RW03.The Architecture Study Program empowerment team provides assistance in the form of equipment that can be used by waste recycling clinics, sewing machines, threads, needles, cloth for bags, and scissors. We also help the need for zippers, and straps for bags, as supporting material for the production of recycled goods.

\section{CONCLUSION}

When PKK mothers have run a recycled product business, members of the Recycling Clinic are having a hard time getting trash coffee packs. So that recycled clinicians aside from storing their own household plastic waste, searching and collecting also from neighbors or traveling beverage sellers, as raw material for $3 \mathrm{R}$ craft products.Most clinic members market their products to their relatives and neighborhoods.Changes in mindset towards disposing of garbage, are automatically formed, based on the needs of the people themselves, according to the economic value of waste for them.

This mentoring activity succeeded successfully with the assistance of KSM and BKM who plunged directly to provide understanding to the community. KSM and BKM are the primary level community mobilizers that are received directly by the community.If the Recycling Clinic program activities can be carried out in every village or village that has a large potential for waste, we are sure to solve the garbage problem in the city.But again the participation of all parties in marketing the product is very large, so that the people who have the spirit to produce, keep on making it as a side livelihood and solving environmental problems.

\section{REFERENCES}

Blackwell. Science.“Jokowi Benahi 360 Area Kumuh dalam Lima Tahun”; www.tempo.com

Blower, A. (1993). Planning for a Sustainable Environment : A Report by Town and CountryPlanning Association. Earthscan Publication. London. 
Danur, A. S., \&Ida. (2005). Seminar Nasional : Pembangunan Lingkungan Perkotaan di Indonesia. Jakarta.

Diningrat, R. A. “Bekerjasama Memperbaiki Kampung Kumuh”, URB.IM

Dyah, A., Kurniasih, S., \&Suryandari, P. (2015). Ibm Menuju Kampung Recycle di Petukangan Utara, Laporan PPM.Graham, P. (2002). Building Ecology : First Principle for a Sustainable Built Environment.

Leitman, J. (1999). Sustaining Cities : Environmental Planning and Management in Urban Design.

London, Madrid, Mexico City, Milan, Montreal, New Delhi, San Juan, Singapore, Sydney, Tokyo, Toronto.

Mcgraw- Hill. New York, San Fransisco, Washington DC, Auckland, Bogota, Caracas, Lisbon.

Nasution, S. (2003). Metode Penelitian Naturalistik Kualitatif. Penerbit Tarsito. Bandung.

Netty, D.K. (2015) Program CSR BerbasisPemberdayaanMasyarakat (UntukmeningkatkanProduktivitasUsaha Mikro, Kecil, Menengah di Madura),JurnalNeOBis, Volume 9 No.1 2015

Wheeler, M. (2004). Planning for Sustainability : Creating Livable, Equitable, and Ecological Communities. Routledge. London and New York. 